
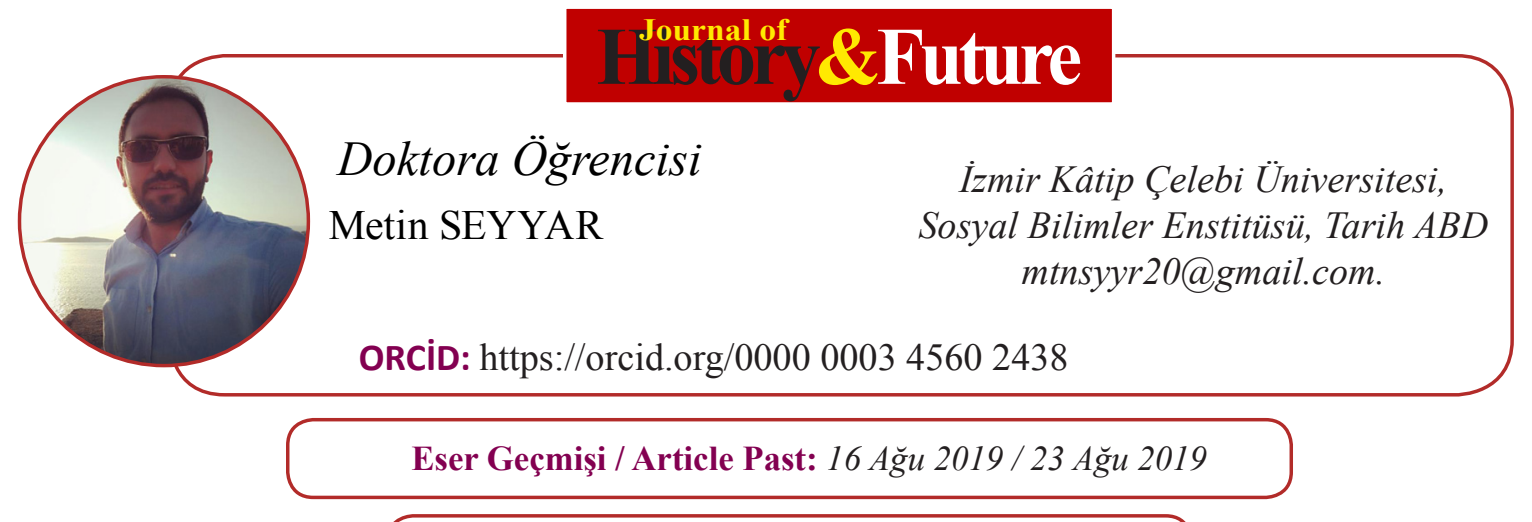

Orjinal Makale / Orginal Paper

\title{
11784 Nolu Temettuât Defterine Göre Evlâd-I Fâtihân Karyelerinden Otmanlı Karyesi'nin 1845 Yılındaki Sosyo- Ekonomik Durumu
}

\author{
Socio-Economic Status Of The Otmanli Village, A Village Of
} Evlâd-I Fâtihân, In 1854 As Per The Tax Registry No. 11784

\section{$\ddot{O} z$}

Tapu tahrir geleneğinin bir devamı olan temettuât defterleri XIX. yüzyılda Osmanlı Devleti’nin mikro düzeyde sosyo-ekonomik yapısı hakkında önemli bilgilere kaynaklık etmiştir. Ele alınan makalede Selanik Kazası Lankaza (Langaza) Nahiyesi Evlâd-1 Fâtihân karyelerinden Otmanlı Karyesi'nin ML.VRD.TMT.d. 11784 nolu temettuât defteri ele alınmıştır. Bu bağlamda, defterde söz konusu karyenin demografik yapısı, karyede bulunan şahıslar, bu şahısların menkul-gayr-1 menkulleri, hangi meslekle uğraştıkları, hayvan türleri, yetiştirilen ürünler, gelir-vergi kalemi üzerinden istatistiki verileriyle ele alınıp değerlendirilmiştir.

Anahtar Kelimeler: Otmanlı, Karye, Temettuât, Gelir, Vergi, Kuruş.

\section{Abstract}

Tax registry books (Temettuât defterleri), which were a continuation of the tradition of land registry( Tapu Tahrir), have been a source of important information about the socio-economic structure of the Ottoman Empire in the micro level. The article we discuss here deals with the tax registry book no. ML.VRD.TMT.d. 11784 of the Otmanlı Village, one of the Evlâd-1 Fâtihân villages in the Lankaza (Langaza) sub-district of the Thessaloniki District. In this context, the demographic structure of the said village, the residents of the village, the movable and non-movable properties of these residents, their occupations, the species of animals bred, and the crops grown as specified in the book shall be assessed by statistical data through the income and tax items.

Keywords: Otmanlı, Village, Tax Registry, Income, Tax, Kuruş. 


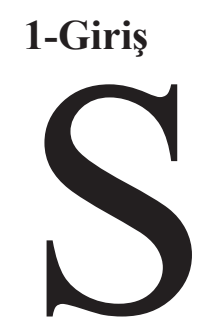

özlük anlamı olarak "faydalanmak, kâr etmek" anlamında kullanılan temettü Arapça kökenli bir kelimedir. Temettü kelimesinin çoğulu temettuât; kârlar, faydalar anlamında kullanılmaktadır.

Tanzimat'a kadar değişik adlarla halktan alınan vergilerin yerine getirilen Temettû vergisinin kaydedildiği defterlere, "Temettuât Defterleri" adı verilmiştir². Bu defterler, XIX. yüzyıl ortalarında Osmanlı Devleti'nin içinde bulunduğu iktisadi, sosyal ve ticari hayatı ortaya koymaktadır. Tanzimat devrinde, önceleri değişik adlarla alınan vergilerin yerine tek bir verginin ikamesi için hane reislerinin gelirlerinin tespiti maksadıyla yapılan temettü sayımları XIX. yüzyıl ortaları Osmanlı sosyal ve iktisadi tarihi için fevkalade kıymetli bilgiler ihtiva etmektedir ${ }^{3}$. Gerçi temettuât defterleri, devrin bir diğer kaynăğ nüfus istatistikleriyle birlikte söz konusu yüzyıl için nispeten önemli veriler sağlamaktaysa da, tahrir defterlerinin zenginliğine sahip değillerdir.

Ayrıca temettuâtlar aynı zamanda birer nüfus defteri gibi de düşünülmüştür. XIX. yüzyıl Osmanlı Devleti'nde mali düzenlemeler anlamında reformların yapıldığı bir dönemdir. Bu anlamda Tanzimat yönetimi, mali yönetimini yeniden düzenleyerek devlet gelirlerini önemli ölçüde artırma konusunda oldukça başarılı adımlar atmıştırs. Bu düzenlemelerin sağlıklı bir yapıda sürdürülmesi için ekonomik olarak potansiyelinin bilinmesi gereklidir ${ }^{6}$.

Temettü defterlerinde kayıt altına alınan binek hayvanlarından verginin alınması için bu hayvanların (at, eşek, katır), sahibi tarafından herhangi bir işte ticari olarak kullanılması yeterli görülmektedir. Temettuât defterlerinde kaza, köy gibi iskân merkezleri mahallelere ayrılmış olup, bu mahalleler hane esasına göre kaydedilmiştir. Bu defterlerde yerleşim yerlerindeki evlerin numaralarının altına kişilerin isimleri, unvan veya lakaplarıyla birlikte yazılmıştır. Bunu takiben hane reislerinin sahip oldukları menkul ve gayr-1 menkul ile bunların gelirleri ve bu gelirlerden verilen vergiler kayıt altına alınmıştır?.

İstatistik verilerin yanı sıra toplumsal yaşama dair bilgiler de sunan bu defterler ayrıca köyde vergi ile yükümlü kişiler üzerinden köyün ekonomik durumu hakkında da önemli bilgiler vermektedir. Emlak, arazi ve bu araziden elde edilen gelirler ile hayvan sayımlarının yapıldığı defterler bu açıdan önemli bilgiler ihtiva etmektedir.

Temettuât sayımları mahalli idareciler tarafından yapılmıştır. H-1256'daki sayımlardan

1 Ali Nâzimâ-Faik Reşad, "Temettü” Mükemmel Osmanlı Lügati, Türk Dil Kurumu Yayınları, İstanbul 2009, s.516 ; ayrıca bknz, Ferit Devellioğlu, (1996), “Temettü-Temettüat”, Osmanlıca - Türkçe Ansiklopedik Lügat ${ }^{23}$, Aydın Kitabevi Yayınları, Ankara 2006, s. 1073, ; Mehmet Kanar, Osmanlı Türkçesi Sözlüğü, s.478

2 Mübahat Kütükoğlu, Osmanl Sosyal Ve İktisadi Tarihî Kaynaklarından Temettü Defterleri, Belleten, LIX/225 1995: s. 395,

3 Mübahat Kütükoğlu, a.g.m., 1995, s. 395, 412.

4 Küpeli, Özer, Klasik Tahrirden Avârız Tahririne Geçiş Sürecinde Tipik Bir Örnek: 1604 Tarihli Manyas Kazası Avârız Defteri (16 belge ile birlikte), Türk Tarih Kurumu Belgeler, 2012, s.114.

5 Tevfik Güran, Tanzimat Dönemi Osmanlı Maliyesi, İstanbul Üniversitesi İktisat fakültesi Mecmuası, C. 49, 1988, s. 91.

6 Nuri Adıyeke, Temettuat Sayımları Ve Bu Sayımları Düzenleyen Nizamname Örnekleri, OTAM, , C. XI, S. XI, 2000, s.771.

7 Gülin Öztürk-Şenay Karaçam Çam, Temettuat Defterlerine Göre 19. Yüzyılın Ortalarında Priştine, Türklük Bilimi Araştırmaları, S/30, 2011, s.285. 
muhassıllar mesul olup, aynı tarihli bir temettü defterinde muhassıl, müfti, mal ve emlak kâtipleri ve meclis azalarının mühürleri bulunmaktadır. H-1261'de sistemde değişiklik yapıldığından Müslümanların yazılması mevcut ve önceki muhtarlar ile köy imamları; gayr-i Müslimlerin yazılması, varsa kocabaşılarla papazların sorumluluğu altında olup defterin bitiminde mühürleri vardır.

Osmanlı araştırmalarına kaynaklık eden en büyük memba şüphesiz Osmanlı Arşivi'dir'9. Türkiye'de Temettuât defterleri üzerine yapılan ilk çalışmaların başında Tevfik Güran'ın çalışması ${ }^{10}$ gelmektedir. Güran'ın bu çalışmasının yayınlandığı tarihten sonra dört çalışmas $1^{11}$ daha bulunmaktadır. Ayrıca Mübahat Kütükoğlu'nun 1995 yılında yaptığı çalışma ${ }^{12}$ bu alandaki önemli temettuâtların başında gelmektedir. Kütükoğlu, söz konusu çalışmasında bu defterlerin genel bir değerlendirmesini yapmıştır. Said Öztürk'ün 1996 yılında yayınladığı makale ${ }^{13}$, yukarıda yapılan çalışmaların devamı niteliğinde önemli bir temettü değerlendirmesidir.

Tevfik Güran, ilk olarak Osmanlı Arşivi’nde katalog çalışmaları yapılmadan önce Kamil Kepeci tasnifinden elde edilen bilgiler ışığında çalışmalarını ele almıştır. Daha sonra yapılan çalışmaların Maliyeden Müdevver tasnifinin yapılması ile birlikte temettuât çalışmaları üzerine yapılan akademik araştırmalarda artış olduğu görülmektedir. Maliye Nezareti Defter serisi altında 9 ana grupta toplanmıştır. Temettuât defteri bu seri altında bulunmaktadır ${ }^{14}$. Selanik Kazası Langaza Nahiyesi'nde H-29-12-1261 tarihli toplam 47 temettuât defteri mevcuttur. Ayrıca bunların içinde Evlâd-1 Fâtihân karyelerinden 12'sinin temettuât defteri yer almaktadır.

Tanzimat ülkenin bütününde uygulanmadığından temettuât defterleri de Tanzimat'in cari olduğu bölgeleri kapsamaktadır. Bu bölgeler şunlardır; Ankara, Aydın, Bolu, Cezayir-i Bahr-i Sefid, Edirne, Erzurum, Hüdavendigar, Konya, Niş, Rumeli, Selanik, Silistre, Üsküb, Vidin ${ }^{15}$.

Maliye Varidat Kalemi defterlerinden olan temettü defterleri, Başbakanlık (Şuan Cumhurbaşkanlığı) Osmanlı Arşivi’nde bulunmaktadır ${ }^{16}$. Bu defter serisi, Kamil Kepeci ve Maliyeden Müdevver Defterler tasnifi içerisinde yer almaktadır. Bu defterler 1988 yılında ayrı olarak tasnif edilmiş ve 17.747 tanesi araştırmaya açılmıştır. Defterlerin büyük kısmı 1844-1845 (H. 1260-1261) tarihinde yapılan sayımlara aittir ${ }^{17}$.

8 Mübahat Kütükoğlu, a.g.m.,1995, s.397-398.

9 Said Öztürk, Türkiye’de Temettuât Çalışmaları, Türkiye Araştırmaları Literatür Dergisi, C. I, S. I, 2003, s.287.

10 Tevfik Güran, On dokuzuncu Yüzyıl Ortalarında Ödemiş Kasabası'nın Sosyo-Ekonomik Özellikleri, İ̈İF, Ord. Prof. Dr. Ömer Lütfi Barkan'a Armağan Özel Sayıs1, İstanbul 1985.

11 Tevfik Güran, 19.Yüzyıl Osmanlı Tarımı, İstanbul 1998., Osmanlı Tarım Ekonomisi, 1840-1910”, İ̈̈IF, Türk İktisat ve İçtimaiyat Tarihi Araştırmaları Merkezi, Türk İktisat Tarihi Yıllığı, S. I, İstanbul 1988., Ziraî Politika ve Ziraatte Gelişmeler, 1839-1876, 150. Yllında Tanzimat, Ankara 1992., 19. Yüzyll Temettuât Tahrirleri, Osmanl Devleti'nde Bilgi ve İstatistik, Ankara 2000. Bknz. Said Öztürk, a.g.m., 2003, s.297.

12 Mübahat Kütükoğlu, Osmanlı Sosyal ve İktisadi Tarihî Kaynaklarından Temettu Defterleri, Belleten, LIX/225 (1995).

13 Said Öztürk, Tanzimat Döneminde Bir Anadolu Şehri Bilecik, İstanbul 1996.

14 Bknz. Başbakanlık Osmanlı Arşiv Rehberi, İstanbul 2010, s.285-286.

15 Said Öztürk, a.g.m., 2003, s. 292.

16 Mübahat Kütükoğlu, a.g.m., 1995, s. 395.

17 Mübahat Kütükoğlu, a.g.m., 1995, s.396. ayrıca bknz, Zafer Atar, Balkanlarda Temettuat Tahriri(TirhalaÜsküp-Drama Sancaklarl Örneklerinde), Türk Dünyası İncelemeleri Dergisi / Journal of Turkish World Studies, C. XII, S. II, 2012, s. 391 
2019 y1lı itibariyle Yüksek Öğretim Kurumu Tez kataloğunda temettuât defterlerine ilişkin kayda değer şekilde Yüksek Lisans tez çalışmalarının olduğu görülmektedir. Bu anlamda temettü defterleri ağırlıklı olarak tarih alanında çalışılmasına rağmen iktisat (ekonomi) alanında da bu defterlerin kullanıldığı çalışmalara rastlamak mümkündür.

Bu çalışmada, Cumhurbaşkanlığı Osmanlı Arşivi'nde bulunan ML.VRD.TMT.d. 11784 nolu defterin Selanik kazası, Lankaza (Langaza) nahiyesi, Evlâd-1 Fâtihân karyelerinden Otmanlı Karyesi'ni içeren veriler ele alınmıştır. Söz konusu olan bu defter, H-29-12-1261 (29 Aralık 1845) tarihinde kayda geçirilmiştir. Defterde karyenin iktisadi ve sosyo-ekonomik yapısı, elde edilen istatistiki veriler esas alınarak değerlendirmeye tabi tutulmuştur. Bahse konu olan defterde okunamayan yerler [...] ve emin olunamayan bazı özel isimler [?] şeklinde gösterilmiştir.

\section{2-Evlâd-ı Fâtihân ve Otmanlı}

Evlâd-1 Fâtihân tabiri genel olarak Rumeli'nin fethi sırasında Anadolu' dan göç ettirilip bu bölgeye iskân edilen Türkleri ifade etmektedir ${ }^{18}$. Bu adlandırma, teşkilat altına alınmış olan Türkmen veya Yörük grupları için XVII. yüzyıl sonlarında kullanılmaya başlanmıştır ${ }^{19}$. Yörüklerin ilk olarak Rumeli'ye iskân ettirilmeleri, Yıldırım Beyazıd döneminde olduğu kabul edilmektedir. Osmanlı Devleti'nin Batı sınırlarında, yeni yurtlar tesis etmek isteyen muhtelif göçebe Oğuz kabilelerinin daha XIV. asır ortalarında Rumeli>ye geçirildikleri bilinmektedir ${ }^{20}$. Bu bağlamda "Rumeli'de Yörüklerin yoğun halde bulundukları yerin Selânik ve havalisi olduğu, XVIII. asır başlarındaki tahavvülden ve hepsinin birden Evlâd-1 Fâtihân adını almasından sonra Selanik’te oturduğu malûmdur" ${ }_{21}$. Bu teşkilat, varlığını XIX. yüzyıl ortalarına kadar devam ettirmiştir. Nitekim bu teşkilata 1828 yılında yapılan düzenlemeye göre askeri hizmet veren neferlerin, yaptıkları göreve karşılık muafiyetleri devam etmekle birlikte diğer askeri gruplarda olduğu gibi düzenli talim yapmaları usulü getirilmiştir²2. Söz konusu teşkilat, varlığını XIX. yüzyıl ortalarına kadar devam ettirmiştir.

Çalışmada ele alınan Otmanlı Karyesi'nin ismini, Osmanlı Kalenderilik tarihinde önemli bir yere sahip olan, Balkanlar'da XV. yüzyıl Kalenderiliğine damgasını vurmuş ve etkisi sonraki dönemlerde de devam etmiş olan ${ }^{23}$ Otman $\mathrm{Baba}^{24}$ dan alıp almadığı konusunda net bir bilgi yoktur.

18 Yusuf Hallaçoğlu, Evlâd-1 Fâtihân, Türkiye Diyanet Vakfi Íslam Ansiklopedisi (TDVİA), C. XI, 1995, S.524.

19 Yusuf Hallaçoğlu, a.g.m., 1995, s.524.

20 M. Tayyib Gökbilgin, Rumeli'de Yürükler, Tatarlar ve Evlâd-l Fâtihân, Osman Yalçın Matbaası, İstanbul 1957, s. 13-14.

21 M. Tayyib Gökbilgin, a.g.e.,1957, s.74.

22 Yusuf Hallaçoğlu, a.g.m., 1995, s. 525.

23 Yusuf Hallaçoğlu, a.g.m., 1995, s.8

24 Ahmet Yaşar Ocak, Otman Baba (Küçük Abdal) menâkıbnâmesine dayanarak şunları kaydetmişti; “Otman Baba 1402'de Timur'la birlikte Anadolu’ya gelmiştir. Germiyan, Saruhan ve çevresinde uzun müddet dolaşmış, II. Mehmed'in şehzâdeliğindeki Manisa valiliği sırasında burada bulunmuştur. Otman Baba’nın H-780/M-1378-9'da doğduğu metinde açıkça kaydedilmiştir. Asıl adının Hüsam Şah olduğu, fakat Otman Baba lakabıyla ün saldığı rivayet olunur. Menâkıbnâmedeki pasajlar, şeyhin şiddetli bir cezbeye sahip bulunduğunu, en yüksek rütbedeki devlet adamlarıyla bile azarlayarak konuşacak kadar kimseden pervası olmayan bir şahsiyete malik olduğunu aksettirmektedir. Yapılan tasvirlere bakılırsa, onun da Abdal Musa, Kaygusuz Abdal ve Sultan Şucâüddîn gibi bir Kalenderî şeyhi olduğu görülür. Nitekim hem kendinin hem de müridlerinin başları, kaşları, sakal ve bıyıkları ustura ile tıraş edilmiştir. Yarı çıplak bir halde diyar diyar dolaşırlar. Anlaşıldığına göre Otman Baba zaman zaman Rumeli'deki fetihlere gazilerle birlikte katılmış, bu sebeple onlardan pek çoğu kendisine mürid olmuştur. Otman 


\section{3-Karye Hakkında Genel Değerlendirme}

Selanik Kazası Evlâd-ı Fatihân Karyelerinden Otmanlı Karyesi'nde toplamda 151 kişi kayıt altına alınmıştır. Bu kişilerin önemli bir kısmının çiftçilikle meşgul olduğu görülmektedir. Ancak karye sakinlerinin hibrit (karma) bir ekonomik uğraş içerisinde olduğunu da söylemek mümkündür. Kayıtlara "erbab-1 ziraat" olarak yansımış olmalarına rağmen gelirleri ile sahip olduklarına bakıldığında tarım arazileri dışında büyükbaş ve küçükbaş hayvanlara da sıkça rastlanılmaktadır. $\mathrm{Bu}$ durum, karye ahalisinin sadece tarımla uğraşmadığına bir kanıt niteliğindedir.

Temettuât kayıtları arasında göze çarpan temel hususlardan birisi rakamların birbirini tutmamasıdır. Öyle ki karyede ikamet eden 151 kişinin toplam temettüleri 83078 kuruş olarak kayda geçirilmiş olmasına rağmen hesaplamalarımız neticesinde 83034 kuruş olduğu görülmüştür. Benzer şekilde toplanan vergilerde de yanlış hesaplamalar olduğu dikkat çekmektedir. Defterin en sonunda karyeden 6787 kuruş vergi toplanıldığ 1 belirtilmiştir. Ancak toplanan vergi tutarı 6778 kuruştur. Rakamlar arasında çok büyük bir fark olmamasına rağmen bunun belirtilmesi önemli görülmektedir. Altı çizilmesi gereken bir başka husus da defterde yanlış hesaplamalara sıkça rastlanıldığıdır. $\mathrm{Bu}$ durum, araştırmacı için bir takım zorlukları ortaya çıkarmıştır.

Defterde ön plana çıkan özelliklere değinilecek olunursa, ilk olarak ödenen en düşük vergi 20 kuruş iken en yüksek verginin ise 55 kuruş olduğu tespit edilmiştir. Otmanlı Karyesi’nde ödenen ortalama vergi tutarı 44,88 kuruştur. Ağırlıklı olarak ise 54 kuruş vergi ödendiği görülmektedir. 151 kişiden 53’ü 54 kuruş vergi ödemiştir. Gelirlere bakıldığında ise en yüksek gelir 1326 kuruş iken en düşük gelir 306 kuruştur. Karye sakinlerinin gelirlerinin ortalaması 547,06 kuruştur.

Tablo 1: Otmanlı Karyesi Sakinlerinin Gelir/Vergi Oranlarının Yüzdelik Dilimleri

\begin{tabular}{|c|c|c|c|c|c|c|c|c|c|}
\hline $\begin{array}{l}\% 5 \text { 'den } \\
\text { az vergi }\end{array}$ & $\begin{array}{c}\text { \%5-6 } \\
\text { Arası } \\
\text { Vergi } \\
\text { Ödeyenler }\end{array}$ & $\begin{array}{c}\text { \%6-7 } \\
\text { Arası } \\
\text { Vergi } \\
\text { Ödeyenler }\end{array}$ & $\begin{array}{c}\% 7-8 \\
\text { Arası } \\
\text { Vergi } \\
\text { Ödeyenler }\end{array}$ & $\begin{array}{c}\text { \%8-9 } \\
\text { Arası } \\
\text { Vergi } \\
\text { Ödeyenler }\end{array}$ & $\begin{array}{c}\% 9-10 \\
\text { Arası } \\
\text { Vergi } \\
\text { Ödeyenler }\end{array}$ & $\begin{array}{c}\text { \%10-11 } \\
\text { Arası } \\
\text { Vergi } \\
\text { Ödeyenler }\end{array}$ & $\begin{array}{c}\text { \%11-12 } \\
\text { Arası } \\
\text { Vergi } \\
\text { Ödeyenler }\end{array}$ & $\begin{array}{c}\text { \%12-13 } \\
\text { Arası } \\
\text { Vergi } \\
\text { Ödeyenler }\end{array}$ & $\begin{array}{c}\text { \%13-15 } \\
\text { Arası } \\
\text { Vergi } \\
\text { Ödeyenler }\end{array}$ \\
\hline 4 & 8 & 22 & 32 & 39 & 19 & 10 & 10 & 3 & 4 \\
\hline
\end{tabular}

Tabloda görüldüğü üzere Otmanlı Karyesi'nde yaşayanlar ağırlıklı olarak gelirlerinin \% 7'si ila \% 9'u arasında bir rakamı temettü vergisi olarak ödemektedirler. Karye halkının gelirlerine göre ödediği ortalama vergi miktarı ise \% 8,16'dır. Ancak bu duruma istisna teşkil eden örneklerde mevcuttur. Örneğin Şa ‘ ban oğlu Salih 704 kuruşluk gelirinin \% 4,97'sini vergi olarak verirken 700 kuruşluk yıllık gelire sahip olan Ahmed oğlu Halil ise gelirinin \% 7,71'ini vergi olarak vermektedir. Şa 'ban oğlu Halil ticaret erbabı olarak kayıtlara "erbab-1 ticaret" olarak geçirilirken Ahmed oğlu Halil "erbab-1 ziraat" olarak kaydedilmiştir. Vergi oranları arasındaki farkın bu yüzden olup olmadığına dair bir şey söylemek pek mümkün görünmemektedir. Gelir/vergi oranı açısından dikkati çeken bir başka isim ise Hüseyin oğlu Mustafa'dır. Mustafa'nın yıllık geliri 1326 kuruş iken ödediği vergi 54 kuruştur. Mustafa gelirinin \% 4,07’sini vergi olarak ödemiştir. Gelir vergi oranı açısından bakıldığında Mustafa gelirine nazaran en düşük vergi veren isim olarak ön plana çıkmaktadır. Otmanlı Karyesi'nde Mustafa gibi 54 kuruş vergi veren birçok isme rastlanırken Mustafa gibi 1000 kuruş üzerinde yıllık gelire sahip bir başka isme rastlanılmamıştır. Karyede ödenen en düşük vergi miktarı ise 20 kuruştur. 20 kuruş vergi ödeyen isimlere bakıldığında bu kişilerin toplam üç kişi olduğu görülecektir. Bu üç kişiden Salih oğlu Yusuf'un yıllık geliri 346 kuruştur. Yusuf 20 kuruş gelir vergisi ödemektedir. Ödediği verginin gelirine oranı ise \%5,78'dir. Hamza oğlu Osman ise

Baba’nın Bulgaristan'daki tekkesi, devrinde ve hattâ daha sonraları en önemli Bektaşî tekkelerinden biri haline gelmiştir”. Ahmet Yaşar Ocak, Alevî ve Bektaşî Inançlarının İslâm Öncesi Temelleri Bektaşî Menâkıbnâmelerinde İslâm Öncesi İnanç Motifleri, İletişim Yayınları, İstanbul 2000, s.44. 
428 kuruşluk gelirinin vergisi olarak 20 kuruş ödemektedir ve gelir-vergi oranı \% 4,67'dir. Ancak yukarıda zikredilen örneklerin hiçbiri Otmanlı Karyesi'ni bir bütün olarak yansıtmamaktadır. Söz konusu kayıtlar farklı örnekler olmaları hasebiyle ele alınmıştır. Karye sakinlerinin genelinin gelir-vergi oranı \% 7 ila \% 9 arasında değişmektedir. 151 sakini bulunan karyede 32 kişi gelirinin \% 7-8' ini vergi olarak öderken 39 kişi ise \% 8-9'unu vergi olarak ödemiştir. Bu da vergi toplanırken belli kıstaslara dikkat edildiğini ortaya koymaktadır.

Son olarak değinilmesi gereken bir diğer husus karyede üç adet değirmen bulunmaktadır. $\mathrm{Bu}$ değirmenlerden elde edilen toplam gelir 1180 kuruştur. Bu durum, karyenin ürettiği tahılı işleyebilme kapasitesini göstermesi açısından kayda değerdir. Değirmen işleten üç neferin meslek türü olarak ticaret erbabı kısmına kaydedildikleri, karyede mevcut tek hanı işleten kişinin meslek türünün ise ziraat erbabı olarak kayıtlara yansıdığı görülmektedir.

\section{4-Karyedeki Meslekler ve Kullanılan İsimler}

Defterde kayıtlı meslek gruplarına bakıldığında 11 'inin hizmetkâr, 33'ünün tüccar ve 107'sinin ziraat erbabı olarak işlendiği görülmektedir. Karyede bu üç meslek grubu dişında demirci, deveci gibi gruplara rastlanılmaması ilginçtir. Çoban mesleği ile uğraşan sadece bir şahıs (Yusuf oğlu İbrahim) bulunmaktadır. İbrahim'in meslek olarak ticaret erbabı kaydedilmesi dikkati çekmektedir.

Karye sakinleri deftere "Mehmed oğlu İbrahim", "Hamza oğlu Osman" şeklinde geçirilmiştir. Bazı hanelerde ise birden fazla vergi mükellefi bulunmaktadır. Bu tür durumlarda ise varsa "Hasan oğlu Ali hanesinden karındaşı Hüseyin ve diğeri Salih" örneğinde olduğu gibi "karındaşı", "oğlu" ve "diğeri" tercih edilmiştir. Karyede iki kişi hacca gidenler için kullanılan "el-hâc" lakabı ile kaydedilmiştir. Ayrıca karyede kullanılan isimlere bakıldığı vakit peş peşe ya baba adları veya temettü sahiplerinin adlarından yola çıkarak akraba oldukları sonucuna varılabilir. Şahıs adları da dikkat çekmektedir.

Grafik 1: Temettü sahiplerinin isimleri

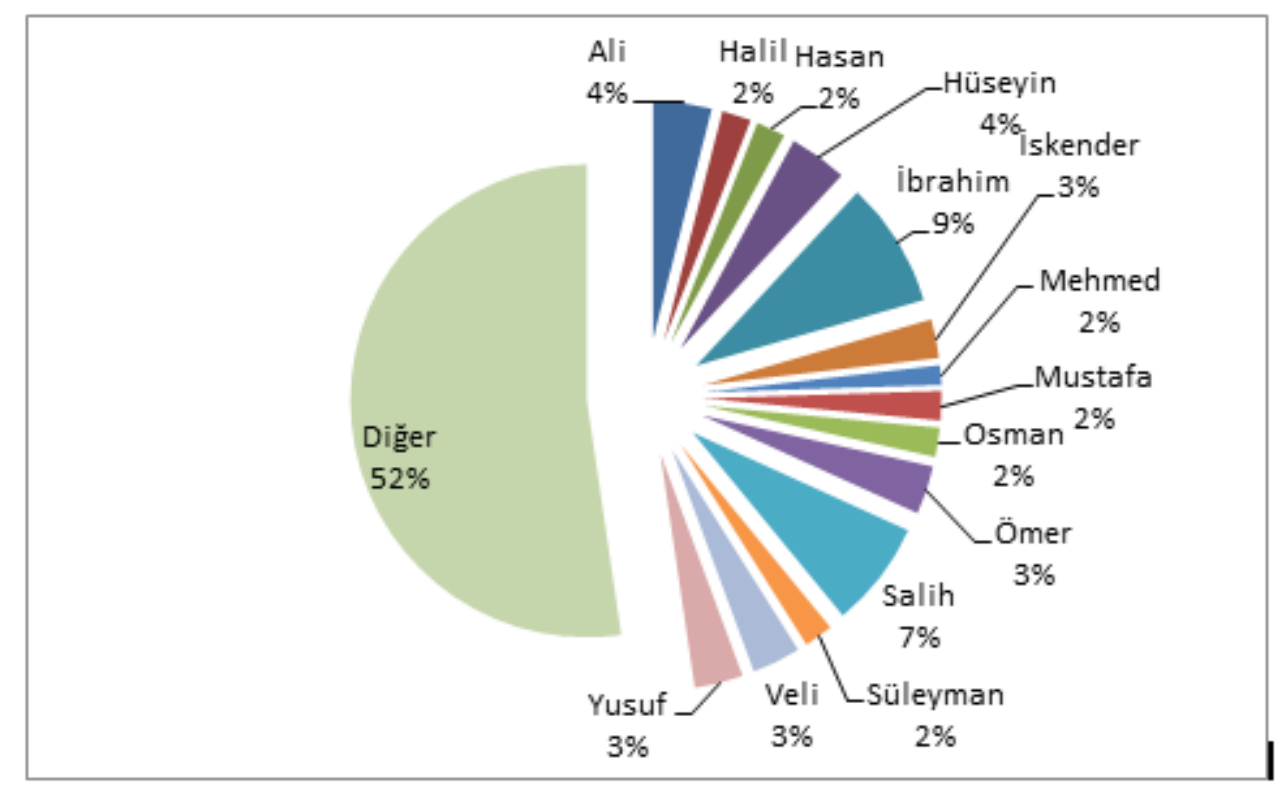


Grafik 2: Babalarının isimleri

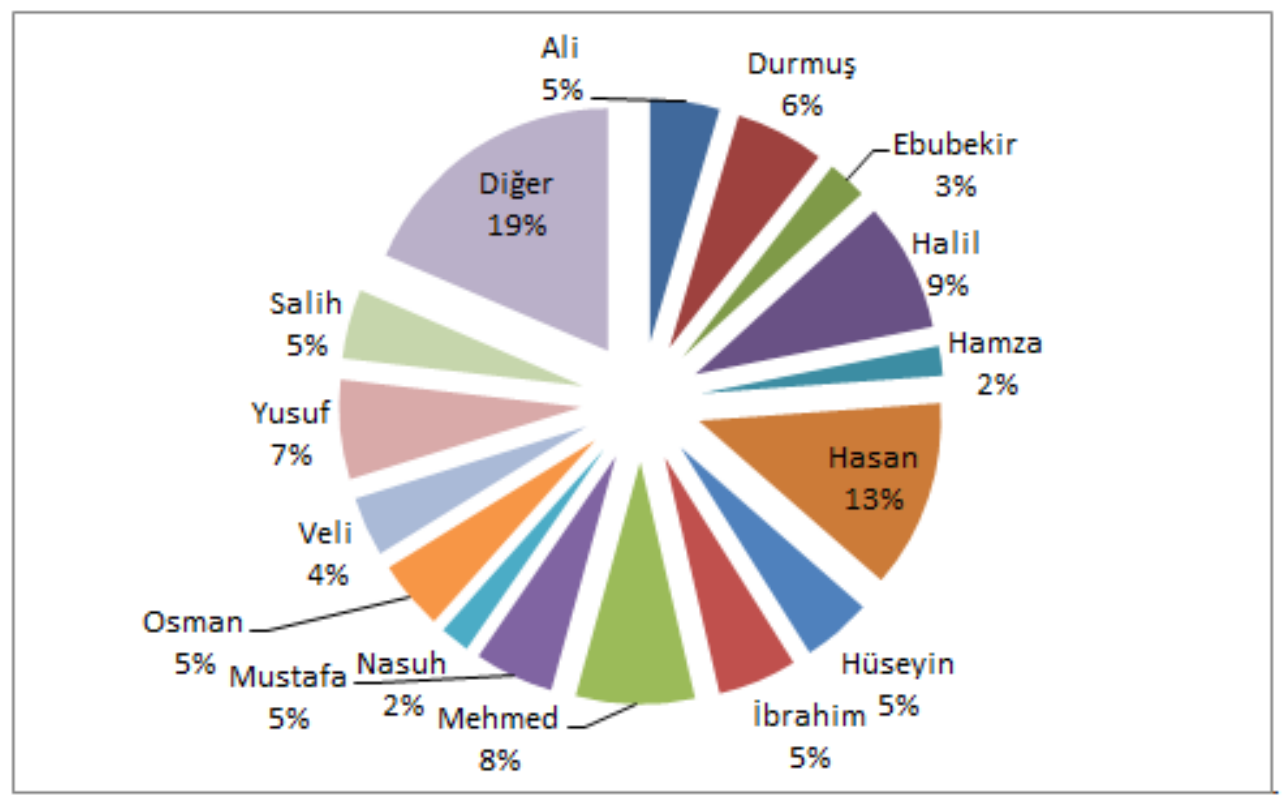

Otmanlı Karyesi’nde kullanılan isimlere bakıldığında isimlerin önemli bir kısmının Arapça olduğu görülmektedir. Gelir sahipleri arasında ön plana çıkan isim İbrahim iken baba isimleri arasında Hasan ismi en çok kullanılan isimdir. Oğul ve baba isimleri karşılaştırıldığında ise oğullardaki isim çeşitliliğinin baba isimlerine göre arttı̆̆ görülmektedir. Pasta grafiğinde de gösterildiği gibi diğer kategorisi oğullarda \% 52 gibi büyük bir orana sahipken baba isimlerinde diğer kategorisi \% 19'dur.

\section{5-Otmanlı Karyesi'nde Ziraat}

Otmanlı Karyesi’nin temel üretim aracı zirai ürünlerdir. Zirai ürünler arasında da hububat türü ön plana çıkmaktadır. Buğday, arpa ve darının yanı sıra üzüm de üretilmektedir. Toprak sahiplerinin önemli bir kısmı aynı zamanda bağlara sahiptir. Temettuât kayıtları arasında dört tip toprak girdisine rastlanılmıştır. Bunlardan ilki mezru' tarladır. Yani kişinin sahip olduğu ve ekip biçtiği tarladır. Şahısların bu tarlalardan elde ettikleri gelirler iki yıl halinde yıllar belirtilerek kayıtlara geçilmiştir. Kişinin sahip olduğu ancak ekip biçmediği haldeki tarlaya ise gayri mezru' tarla denilmiştir. Tarlanın dönümleri verilmiştir ancak ekilip biçilmediği için buralardan yıllık gelir defterlere geçirilememiştir. Bir başka tarla çeşidi ise karye sakininin müstecir olduğu yani kiraladığ 1 tarlalardır. Son olarak ise sahip olunup kiraya verilen tarlalar kayıtlara geçmiştir. Otmanlı Karyesi sakinlerinden 94 kişinin yani \% 62,25'inin tarlası kendine aittir ve orada tarımsal faaliyette bulunmuştur. Tarla kiralayan kişi sayısı ise 20'dir. Hem tarla sahibi olup hem de tarla kiralayan bir isme rastlanılmamıştır. 
Tablo 2: Tarla Sahiplerinin Tarlalarının Büyüklükleri

\begin{tabular}{|c|c|c|c|c|c|c|}
\hline $\begin{array}{c}10 \text { dönüm } \\
\text { ve altı }\end{array}$ & $\begin{array}{c}\text { 11-20 dönüm } \\
\text { arası }\end{array}$ & $\begin{array}{c}\text { 21-30 dönüm } \\
\text { arası }\end{array}$ & $\begin{array}{c}\text { 31-40 dönüm } \\
\text { arası }\end{array}$ & $\begin{array}{c}41-50 \text { dönüm } \\
\text { arası }\end{array}$ & $\begin{array}{c}51-60 \text { dönüm } \\
\text { arası }\end{array}$ & $\begin{array}{c}61 \text { dönüm } \\
\text { ve üzeri }\end{array}$ \\
\hline 5 & 45 & 32 & 8 & 2 & 1 & 1 \\
\hline
\end{tabular}

Tablo 3: Tarla Kiralayan Kişilerin Tarlalarının Büyüklükleri

\begin{tabular}{|c|c|c|}
\hline 10-20 dönüm arası & 21-30 dönüm arası & 31 dönüm ve üzeri \\
\hline 16 & 3 & 1 \\
\hline
\end{tabular}

Karyedeki toprakların büyüklükleri tabloda belirtildiği şekildedir ve kendi tarlasına sahip kişilerin ağırlıklı olarak 11-30 dönüm arasında tarlaya sahip olduğu görülmektedir. 11-20 dönüm arası toprağa sahip kişi sayısı 45 iken 21-30 dönüm toprağa sahip kişi sayıs1 32' dir. Toplamda ise 94 kişiden 77'si görüldüğü üzere 11-30 dönüm toprağa sahiptir. Ahmed oğlu Hüseyin Otmanl1 Karyesi'nde en geniş araziye sahip kimse olarak kayıtlara geçirilmiştir. Hüseyin'in 118 dönüm tarlası bulunmaktadır. Hüseyin tarlasından H-1260 yılında 780, H-1261 yılında ise 740 kuruş gelir sağlanmıştır. Ödediği vergilere bakıldığında Hüseyin'in zirai üretimi hububattır. Hububatın yanı sıra da 1 dönümlük bağında üzüm yetiştirdiği kayıtlara yansımıştır. En geniş araziye sahip olması Hüseyin'i yıllık gelir olarak en yukarı taşımamıştır. Yıllık geliri 762 kuruştur. Ödediği gelir vergisi ise 55 kuruştur ki 55 kuruş yukarıda da belirtildiği üzere Otmanlı Karyesi'nde alınan en yüksek vergi miktarıdir.

Tarla kiralayanlar incelendiğinde ise toplam 20 kişi ile karşılaşılmıştır. 20 kişinin 16'sı 1020 dönüm arası toprak kiralamıştır. Tarla kiralayanların da tarla sahipleri gibi 10-20 dönüm arası toprakta tarımsal faaliyette bulunduğu görülmektedir. Yalnızca Mehmed oğlu Salih diğer müstecirlerden farklı olarak 100 dönüm toprak icar etmiştir. Salih müstecir olduğu tarladan H-1260 yılında 620 ve H-1261 yılında 610 kuruş gelir sağlamıştır. Salih'in de Hüseyin gibi 1 dönüm bağı vardır. Tarımını yaptıkları ürünlerde Hüseyin ile benzerlik taşımaktadır. Salih'in de hububat ve üzüm üreticisi olduğu görülmektedir. Y1llık geliri 619 kuruş iken ödediği vergi tutarı 40 kuruştur.

Karyede, toplam 141 kişinin bahçeye sahip olduğu, bahçeden elde edilen gelirin iki y1llık geliri totalde 15133 kuruştur. Elde edilen geliri kişi başına 1.12 çıkmaktadır. Temettuâtta H-1261 (M-1845) yılında toplamda 7737 kuruş elde edilmiş ve kişi başına ise 54.48 kuruş düştüğü hesaplanmiştır.

Tahıl üreten kişi sayısı 108, üzüm üreten ise 135 kişi olarak kaydedilmiştir. Bu anlamda bahçe meyvelerinden üzüm yetiştiriciliğinin daha yaygın olduğu ifade edilebilir. Karyede pamuk üretiminin yapılmadığı ve arıcılık ile uğraşan kişinin olmadığ 1 tespit edilmiştir.

Son olarak toprak ve topraktan elde edilen gelirlerle ilgili olarak altı çizilmesi gereken bir başka husus ise zirai üretim sonucu elde edilen gelirlerin yıldan yıla büyük oranda dalgalanma yaşamadığıdır. Genellikle 10-20 kuruş arasında farklılıklar görülmektedir. Üretilen ürünlerse Hüseyin ve Salih örneklerinde de görüldüğ̈̈ üzere hububat ve üzümdür.

\section{6-Otmanlı Karyesi'nde Hayvancılık}

Otmanlı Karyesi’nin üretim araçlarının karma yapıda olduğuna yukarıda değinmişti. Karyenin en önemli meslek grubunu ziraat erbabı oluşturmaktadır. Ama dikkatle incelendiğinde Otmanlı 
Karyesi'nde çok sayıda küçükbaş hayvan olmasına rağmen sadece bir kişinin çoban olarak gelir elde ettiği görülmektedir.

Tablo 4: Küçükbaş Hayvan Sahipleri ve Küçükbaş Hayvan Sayıları

\begin{tabular}{|c|c|c|c|c|}
\hline $\begin{array}{c}\text { Hayvan } \\
\text { Sahiplerinin } \\
\text { Toplam Sayısı }\end{array}$ & $\begin{array}{c}\text { Toplam Küçükbaş } \\
\text { Sayısı }\end{array}$ & $\begin{array}{c}\text { Kişi Başına Düşen } \\
\text { Hayvan Sayısı }\end{array}$ & $\begin{array}{c}\text { Hayvanlardan Elde } \\
\text { Edilen Gelir (kuruş } \\
\text { olarak) }\end{array}$ & $\begin{array}{c}\text { Kişi Başına Düşen } \\
\text { Gelir }\end{array}$ \\
\hline 115 & 3357 & 29.19 & 8514 & 73.39 \\
\hline
\end{tabular}

3357 küçükbaş hayvanı bünyesinde barındıran karyede, verilen rakamdan da görüleceği üzere küçükbaş hayvan yetiştiriciliğinin yapıldığını söylemek yanıltıcı olmayacaktır. 151 kişiden 115'inin küçükbaş hayvana sahip olduğu görülmektedir. Küçükbaş hayvanlara sahip olan kişilerin 6-117 arasında değişen sayılarda küçükbaş hayvanı olduğu kayıtlara yansımıştır. 113 kişinin ortalama küçükbaş hayvan sayısı 29,19'dur. Küçükbaş hayvanlardan karyenin ürettiği toplam gelir 8514 kuruştur ve buda kişi başı 73,39 kuruşa tekabül etmektedir. Karyenin ortalama yıllık gelir miktarının 547 kuruş olduğu göz önüne alındığında gelirlerinin \%13,41'ini yalnızca küçükbaş hayvanlardan kazandıkları görülecektir. Bu rakam elbette üreticinin yatırımlarına göre değişiklik arz etmektedir. Mehmed oğlu Ahmed 60 küçükbaş hayvana sahiptir. Bunların sağman olanlarından y1llık 130 kuruş kazanmaktadır. Adet-i ağnam ${ }^{25}$ vergisi olarak ise 15 kuruş ödemektedir. Ahmed'in y1llık geliri 759 kuruş iken ödediği gelir vergisi ise 54 kuruştur.

Küçükbaş hayvancılığına yatırım yapan bir başka isim ise Yusuf oğlu İbrahim'dir. Karyede en fazla küçükbaş hayvana sahip olan kişi olarak ön plana çıkmaktadır. İbrahim’in 117 adet küçükbaş hayvanı vardır. Yusuf〉un bunlardan sağladığı yıllık gelir ise 509 kuruştur. Bu rakam oldukça yüksektir. Kayıtlara ticaret erbabı şeklinde kaydedilen Yusuf'un küçükbaş hayvan tüccarı olduğunu söylemek yanlış olmayacaktır. Yusuf, adet-i ağnam vergisi olarak 19 kuruş ödemektedir. Ahmed ve Yusuf'un ödedikleri karşılaştırdığımızda ilginç bir durum ortaya çıkmaktadır. Ahmed 60 küçükbaş hayvana karşı 15 kuruş vergi öderken Yusuf’un 117 küçükbaş hayvana karş1 ödediği 19 kuruş oldukça azdır. Bunun nedeni ile ilgili kayıtlarda herhangi bir bilgiye ulaşılamamıştır. Yusuf'un yıllık geliri 960 kuruştur. Gelirinin büyük kısmını küçükbaş hayvanlardan kazanan Yusuf, bunun yanı sıra bağdan yani üzüm üreticiliğinden de gelir elde etmektedir. Ödediği gelir vergisi ise 50 kuruştur.

Büyükbaş hayvan sahipliği de Otmanlı Karyesi’nde oldukça yaygındır. Bu bağlamda büyükbaş hayvanlardan sığır, dana, düve, tosun ve öküzün toplamı 255'tir. Toplamda 113 kişinin büyükbaş hayvanı bulunmaktadır. Kişi başına 2.25 büyükbaş hayvan düşmektedir. 202 adet bulunan İnek ve buzağıya 87 kişinin sahip olduğu kayda geçmiştir. 66 aile bu hayvanlardan 740 kuruş gelir elde etmiştir. Aile başına ortalama 11.38 kuruş gelir düşmektedir.

25 Ağnam resmi; Koyun ve keçilerden alınan ve örfi resimlerin tekâlif cinsinden olan çeşitli vergilerdenł dir. ...Adet-i ağnam resmi başlıca bir kalem teşkil eder ve her mali sene başında birlikte olarak sancak tarafından müzayede ile mültezimlere maktû'en ihâle olunur ve maktu bedelleri hazinece müteahhidv lerinden tahsil olunurdu... Mehmet Ali Ünal, Osmanlı Tarih Sözlüğü, Paradigma Yayınları, Ekim 2011, s. 19. 
Tablo 5: Büyükbaş Hayvan Sahipleri ve Toplam Büyükbaş Sayıları

\begin{tabular}{|l|c|c|c|}
\hline Büyükbaş Türü & Sahip Olan Kişi Sayısı & Toplam Büyükbaş Sayısı & $\begin{array}{l}\text { Kişi Başına Düşen } \\
\text { Hayvan Sayısı }\end{array}$ \\
\hline $\begin{array}{l}\text { Sığır, dana, düve, } \\
\text { tosun ve öküz }\end{array}$ & 113 & 255 & 2,25 \\
\hline İnek ve buzağı & 87 & 202 & 2,32 \\
\hline
\end{tabular}

Karyede bulunan kişilerden 70'inin küçükbaş, büyükbaş, binek hayvanı ve bahçesi, bulunmaktadır. Toplam kişi sayısına böldüğümüzde kişi başına 46.35 gibi yüksek bir rakam çıkmaktadır. Buna ek olarak 7 kişinin de büyükbaş, küçükbaş ve binek hayvanının olduğu görülmektedir. Söz konusu olan 7 kişinin toprağı olmayıp sadece ticaretle uğraştığı anlaşılmaktadır. Yukarıda zikrolunan 70 kişiden 69'u ziraatçı, yalnızca birinin tüccar olduğu kaydedilmiştir. Bu bir kişinin de tarlasını kiraya verdiği kayıtlara yansımıştır.

Binek ve yük hayvanlarından at, bargir, merkeb, deve, kısrak ve taya 112 kişinin sahip olduğu görülmektedir. Bu binek hayvanlarından 199 adet bulunmaktadır. Kişi başına düşen binek sayıs1 1.77'dir. Karyede binek hayvanlarından devenin kayıtlara yansımadığ1 görülmektedir. Bunun nedeni olarak iklim şartlarının buna müsait olmadığı veya deveye olan ihtiyacın hissedilmediği sonucuna varılabilir. Karye'de ayrıca ticaretten gelir sağlayan kişi sayısı 26, emek yolu ile de 11 kişinin gelir sağladığı kaydedilmiştir.

\section{7-Sonuç}

Tanzimat' in ilk yıllarında toplam vergi yükünün ülkenin değişik bölgelerinde yaşayan kişiler arasında eşit dağılımını sağlamak için yapılmış olan Temettuat tahrirlerinin XIX. yüz yıl Osmanlı sosyo-ekonomik tarihi içinde önemli bir yeri vardır.

Otmanlı Karyesi'nin gelir kaynaklarının Ziraat, Ticaret/Hizmetkârlı/Tarım ve Hayvancılık olmak üzere üç grupta toplandığı görülmektedir. Bu gruplar içinde en fazla gelirin tarımdan (tarladan), ikinci sırada hayvancılıktan geldiği söylenebilir. Üretim olarak en fazla gelirin elde edildiği kalemin hububat olduğu ve onu takip eden ürünün ise üzüm olduğu ifade edilebilir. Nitekim tahıl üreten kişi sayısı 108 ve üzüm üreten kişi sayısı ise 135 olarak kaydedilmiştir. Ayrıca karyede arıcılık işi ile pamuk üretiminin yapılmadığı tespit edilmiştir. Verilere bakıldığında karyedeki insanların karyede kendi ihtiyacını karşılayacak kadar hububat ve üzüm yetiştirdiği anlaşılmaktadır.

Temettuat tahrirlerinde yer alan verilerden elde edilen en önemli bilgilerden biri, karye nüfusunun meslekleri ve bu mesleklerden elde ettikleri gelirlerle ilgilidir ${ }^{26}$. Bu bağlamda ele alınan karyede ziraat, ticaret ve hizmetkârlık olmak üzere üç farklı meslek grubunun olduğu ve bu mesleklerden gelir elde edildiği tespit edilmiştir. Ayrıca değirmen işleten üç kişi ile han işleten bir kişinin meslekleri ile ilgili gelir elde ettikleri kayda geçilmiştir.

Karyede, hayvancılığın gelişmiş olduğu istatistiki verilerden anlaşılmaktadır. Zira karyede mukim 151 kişiden 128 'inin hem küçükbaş hem de büyükbaş hayvana sahip olduğu kaydedilmiştir. Otmanlı Karyesi'nde bu hayvan türlerinden toplam 9254 kuruş gelir elde edilmiştir.

Sonuç olarak, söz konusu çalışmada incelenen defterden elde edilen veriler ışığında Otmanlı

26 Tevfik Güran, Ondokuzuncu Yüzyıl Ortalarında Ödemiş Kasabasının Sosyo-Ekonomik Özellikleri, İstanbul Üniversitesi İktisat fakültesi Mecmuas1, C. 41, S. I-IV, 1985, s. 303. 
Karyesi'nin sosyal ve iktisadi açıdan genel bir değerlendirilmesi yapılmıştır. Ancak elde edilen verilerin sınırlılığı, bazı konularda yeterli düzeyde açıklama yapılmasını zorlaştırmıştır. Buna rağmen elde edilen verilerin adı geçen bölgenin sosyal ve iktisadi işleyişine dair ipuçları vermiş olması ziyadesiyle kıymete değerdir.

\section{Kaynakça}

\section{1-Birincil Kaynaklar}

ML.VRD.TMT.d. (Maliye Nezareti Varidat Muhasebesi Temettuât Defteri): 11784 (vr no: $1-61)$.

\section{2-Telif Kaynaklar}

Adıyeke, Nuri, Temettutât Sayımları Ve Bu Sayımları Düzenleyen Nizamname Örnekleri, OTAM, C. XI, S. XI, 2000, s.769-823.

Ali Nâzimâ-Faik Reşad, Mükemmel Osmanlı Lügati, Türk Dil Kurumu Yayınları, İstanbul 2009.

Atar, Zafer, Balkanlarda Temettuat Tahriri(Tırhala-Üsküp-Drama Sancakları Örneklerinde), Türk Dünyası İncelemeleri Dergisi / Journal of Turkish World Studies, C. XII, S. II, 2012, s.389407.

Bizbirlik, Alpay-Atar, Zafer, XIX. Yüzyıl Osmanlı Tarihinde Temettutât Defterleri'nin Yeri: Saruhan Sancă̆ı Mütevelli Çiftliği Temettutât Defteri Örneği, SAÜ Fen Edebiyat Dergisi, 2009/1, s. 37-57.

Devellioğlu, Ferit, “Temettü-Temettüat”, Osmanlıca - Türkçe Ansiklopedik Lügat²3, Aydın Kitabevi Yayınları, Ankara 2006.

Güran, Tevfik, Tanzimat Dönemi Osmanlı Maliyesi, İstanbul Üniversitesi İktisat fakültesi Mecmuas1, C. 49, 1988, s. 79-95.

Güran, Tevfik, Ondokuzuncu Yüzyıl Ortalarında Ödemiş Kasabasının Sosyo-Ekonomik Özellikleri, İstanbul Üniversitesi İktisat fakültesi Mecmuası, C. 41, S. I-IV, 1985, s.301-319.

Hallaçoğlu, Yusuf, Evlâd-1 Fâtihân, Türkiye diyanet Vakfi Íslam Ansiklopedisi (TDVİA), C.11, 1995, s.524-525.

Gökbilgin, M. Tayyib, Rumeli'de Yürükler, Tatarlar ve Evlâd-ı Fâtihân, Osman Yalçın Matbaas1, İstanbul 1957.

Küpeli, Özer, Klasik Tahrirden Avârı Tahririne Geçiş Sürecinde Tipik Bir Örnek: 1604 Tarihli Manyas Kazası Avârız Defteri (16 belge ile birlikte), Türk Tarih Kurumu Belgeler, S. 32, 2012, s. 113-199.

Kütükoğlu, Mübahat, Osmanlı Sosyal Ve İktisadi Tarihi Kaynaklarından Temettü Defterleri, Belleten, C. LIX, S. 225, 1995, s.395-412.

Ocak, Ahmet Yaşar, Alevî̀ ve Bektaşî İnançlarının İslâm Öncesi Temelleri Bektaşî Menâkıbnâmelerinde İslâm Öncesi İnanç Motifleri, İletişim Yayınları, İstanbul 2000.

Öztürk, Gülin -Şenay Karaçam Çam, Temettuât Defterlerine Göre 19. Yüzyılın Ortalarında Priştine, Türklük Bilimi Araştırmaları, S. 30, 2011, s.283-310.

Öztürk, Said, Türkiye'de Temettuât Çalışmaları, Türkiye Araştırmaları Literatür Dergisi, C. 
I, S.I, 2003, s.287-304.

Pamuk, Şevket, Osmanlı Mali İstatistikleri Bütçeler 1841-1918, T.C. Başbakanlık Devlet İstatistik Enstitüsü Tarihi İstatistikler Dizisi Cilt 7, Ankara 2003.

Ünal, Mehmet Ali, Osmanlı Tarih Sözlüğü, Paradigma Yayınları, İstanbul Ekim 2011.

\section{Ekler}

Ek I: Otmanlı Karyesi’nde ikâmet eden kimselerin toplam temettuâları

\begin{tabular}{|c|c|c|c|}
\hline Kişi Adı & Temettutât Toplamı (Kuruş) & Vergi & Vergi Yüzdesi \\
\hline Ali Oğlu İbrahim & 470 & 55 & $\% 11,70$ \\
\hline Ali oğlu Süleyman & 627 & 45 & $\% 7,17$ \\
\hline Salih oğlu Ömer & 391 & 25 & $\% 6,39$ \\
\hline Halil oğlu İsmail & 500 & 25 & $\% 5$ \\
\hline Hüseyin oğlu $[\ldots]$ & 493 & 54 & $\% 10,95$ \\
\hline Satı[?] oğlu İskender & 347 & 45 & $\% 12,96$ \\
\hline Halil oğlu Mustafa & 448 & 35 & $\% 7,81$ \\
\hline Mehmed oğlu İbrahim & 315 & 35 & $\% 11,11$ \\
\hline Mehmed oğlu Ahmed & 759 & 54 & 7,11 \\
\hline Yusuf oğlu İbrahim hanesinden oğlu Hasan & 558 & 54 & $\% 9,67$ \\
\hline Mustafa oğlu Salih & 331 & 24 & $\% 7,25$ \\
\hline Halil oğlu Hasan hanesinden oğlu İsa & 423 & 44 & $\% 10,40$ \\
\hline İbrahim oğlu Hasan & 368 & 44 & $\% 11,95$ \\
\hline Salih oğlu Ali & 446 & 44 & $\% 9,86$ \\
\hline Durmuş oğlu Hasan & 367 & 54 & $\% 14,71$ \\
\hline Halil oğlu Hüseyin & 457 & 54 & $\% 11,86$ \\
\hline Durmuş oğlu Behram & 572 & 44 & $\% 7,69$ \\
\hline Durmuş oğlu Ali & 484 & 35 & $\% 7,23$ \\
\hline $\begin{array}{c}\text { Osman oğlu Salih hanesinden karındaşı } \\
\text { Ömer }\end{array}$ & 362 & 35 & $\% 9,66$ \\
\hline Veli oğlu İbrahim & 395 & 55 & $\% 13,92$ \\
\hline Mehmed oğlu Ömer & 614 & 54 & $\% 8,79$ \\
\hline Martoş[?] oğlu Ali & 481 & 54 & $\% 11,22$ \\
\hline Mehmed oğlu İbrahim & 533 & 35 & $\% 6,56$ \\
\hline $\begin{array}{l}\text { Mustafa oğlu Abdullah hanesinden oğlu } \\
\text { Mehmed }\end{array}$ & 630 & 35 & $\% 5,55$ \\
\hline Şa ban oğlu Salih & 704 & 35 & $\% 4,97$ \\
\hline Ali oğlu Behram & 883 & 54 & $\% 6,11$ \\
\hline Osman oğlu İbrahim & 634 & 54 & $\% 8,51$ \\
\hline Mustafa oğlu Salih & 471 & 44 & $\% 9,34$ \\
\hline Hasan oğlu Süleyman & 599 & 44 & $\% 7,34$ \\
\hline Ahmed oğlu Halil & 700 & 54 & $\% 7,71$ \\
\hline Ahmed oğlu Mahmud & 568 & 54 & 9,50 \\
\hline Ömer oğlu Seydi Ali & 712 & 54 & $\% 7,58$ \\
\hline Hasan oğlu Receb & 424 & 35 & $\% 8,25$ \\
\hline Durmuş oğlu Ahmed & 788 & 54 & $\% 6,85$ \\
\hline Hüseyin oğlu Mustafa & 1326 & 54 & $\% 4,07$ \\
\hline Veli oğlu Mehmed & 601 & 54 & $\% 8,98$ \\
\hline Ali oğlu Nasuh & 573 & 35 & $\% 6,10$ \\
\hline Halil oğlu Ebubekr & 392 & 35 & $\% 8,92$ \\
\hline
\end{tabular}




\begin{tabular}{|c|c|c|c|}
\hline Hüseyin oğlu Hasan & 525 & 54 & $\% 10,28$ \\
\hline Mehmed oğlu Ali & 750 & 54 & $\% 7,2$ \\
\hline Halil oğlu Salih & 679 & 44 & $\% 6,48$ \\
\hline Veli oğlu Salih & 513 & 35 & $\% 6,82$ \\
\hline Hüseyin oğlu İskender & 464 & 40 & $\% 8,62$ \\
\hline İbrahim oğlu Hüseyin & 517 & 40 & $\% 7,73$ \\
\hline Halil oğlu Ahmed & 716 & 50 & $\% 6,98$ \\
\hline Halil oğlu İdris & 679 & 50 & $\% 7,36$ \\
\hline Hasan oğlu Memiş hanesinden oğlu Şa ban & 561 & 50 & $\% 8,91$ \\
\hline Osman oğlu Halil & 668 & 50 & $\% 8,80$ \\
\hline Hamza oğlu Osman & 428 & 20 & $\% 4,67$ \\
\hline Salih oğlu Ebubekr & 590 & 50 & $\% 8,47$ \\
\hline İbrahim oğlu Salih hanesinden oğlu Receb & 601 & 50 & $\% 8,31$ \\
\hline Nasuh oğlu İbrahim & 450 & 40 & $\% 8,88$ \\
\hline Yusuf oğlu Hasan & 457 & 40 & $\% 8,75$ \\
\hline Halil oğlu Ramazan & 434 & 35 & $\% 8,06$ \\
\hline Salih oğlu Yusuf & 627 & 54 & $\% 8,61$ \\
\hline Mustafa oğlu Veli & 476 & 44 & $\% 9,24$ \\
\hline Hüseyin oğlu Veli & 465 & 35 & $\% 7,52$ \\
\hline Seydi oğlu Hüseyin & 400 & 25 & $\% 6,25$ \\
\hline Halil oğlu Osman & 400 & 35 & $\% 8,75$ \\
\hline Hasan oğlu İbrahim & 655 & 54 & $\% 8,24$ \\
\hline Yusuf oğlu Salih & 556 & 54 & $\% 9,71$ \\
\hline Mustafa oğlu Hasan & 306 & 35 & $\% 11,43$ \\
\hline İbrahim oğlu Ali & 520 & 35 & $\% 6,73$ \\
\hline Mustafa oğlu Musa & 570 & 35 & $\% 6,14$ \\
\hline Hüseyin oğlu Salih & 661 & 54 & $\% 8,16$ \\
\hline $\begin{array}{l}\text { Nasuh oğlu Hüseyin hanesinden oğlu } \\
\text { Behram }\end{array}$ & $573+350($ oğlunun $)=923$ & 54 & $\% 5,85$ \\
\hline Ahmed oğlu Veli & 611 & 54 & $\% 8,83$ \\
\hline Mehmed oğlu Halil & 624 & 54 & $\% 8,65$ \\
\hline Hasan oğlu İsmail & 500 & 44 & $\% 8,8$ \\
\hline Ahmed oğlu Ömer & 608 & 44 & $\% 7,23$ \\
\hline Abdi oğlu Ömer & 621 & 54 & $\% 8,69$ \\
\hline El-hac Hamza oğlu Mustafa & 746 & 54 & $\% 7,23$ \\
\hline Süleyman oğlu Ali & 383 & 54 & $\% 14,09$ \\
\hline Ali oğlu Süleyman & 378 & 44 & $\% 11,64$ \\
\hline Yusuf oğlu Hüseyin & 701 & 44 & $\% 6,27$ \\
\hline Hasan oğlu İskender & 538 & 44 & $\% 8,17$ \\
\hline İbrahim oğlu Veli & 727 & 54 & $\% 7,42$ \\
\hline Hasan oğlu Ahmed & 475 & 54 & $\% 11,36$ \\
\hline Mehmed oğlu Halil & 525 & 54 & $\% 10,28$ \\
\hline$[\ldots]$ oğlu Emin & 455 & 44 & $\% 9,67$ \\
\hline Ebubekr oğlu Mirza[?] & 488 & 35 & $\% 7,17$ \\
\hline Mustafa oğlu Mü'min & 509 & 35 & $\% 6,87$ \\
\hline Mahmud oğlu Yusuf & 537 & 54 & $\% 10,05$ \\
\hline Yusuf oğlu Emin & 534 & 44 & $\% 8,23$ \\
\hline Hasan oğlu İskender & 603 & 54 & $\% 8,35$ \\
\hline Hamza oğlu İsa hanesinden oğlu Musa & 528 & 35 & $\% 6,62$ \\
\hline
\end{tabular}




\begin{tabular}{|c|c|c|c|}
\hline Hüseyin oğlu Osman & 527 & 35 & $\% 6,64$ \\
\hline Veli oğlu Ahmed & 505 & 45 & $\% 8,91$ \\
\hline Osman oğlu Hüseyin & 756 & 54 & $\% 7,14$ \\
\hline Mirhalim oğlu Ömer & 608 & 44 & $\% 7,23$ \\
\hline Hasan oğlu Hüseyin & 419 & 35 & $\% 8,35$ \\
\hline Yunus oğlu Ahmed & 536 & 54 & $\% 10,07$ \\
\hline Yusuf oğlu Salih & 496 & 44 & $\% 8,87$ \\
\hline Nasuh oğlu Ali hanesinden oğlu İskender & $620+150($ oğlunun $)=770$ & 55 & $\% 7,14$ \\
\hline Ahmed oğlu Hüseyin & 762 & 55 & $\% 7,21$ \\
\hline Mehmed oğlu Veli & 792 & 54 & $\% 6,81$ \\
\hline Hasan oğlu Ömer & 639 & 54 & $\% 8,45$ \\
\hline Ömer oğlu Ali & 395 & 25 & $\% 6,32$ \\
\hline Salih oğlu Abdurrahman & 646 & 50 & $\% 7,73$ \\
\hline Mehmed oğlu Mahmud & 396 & 25 & $\% 6,31$ \\
\hline Yunus oğlu Ali & 553 & 50 & $\% 9,04$ \\
\hline İbrahim oğlu İsa & 445 & 25 & $\% 5,61$ \\
\hline Abdullah oğlu İsa & 436 & 20 & $\% 4,58$ \\
\hline El-hâc Hamza oğlu Ferhad & 616 & 40 & $\% 6,49$ \\
\hline Durmuş oğlu Tahir & 453 & 54 & $\% 11,92$ \\
\hline Yusuf oğlu İbrahim & 960 & 50 & $\% 5,20$ \\
\hline Hasan oğlu Salih & 630 & 50 & $\% 7,93$ \\
\hline Osman oğlu Hüseyin & 495 & 40 & $\% 8,08$ \\
\hline Durmuş oğlu İbrahim & 414 & 54 & $\% 13,04$ \\
\hline $\begin{array}{l}\text { Hasan oğlu Ali hanesinden karındaşı } \\
\text { Hüseyin diğeri Salih }\end{array}$ & 464 & 44 & $\% 9,48$ \\
\hline Hasan oğlu Hüseyin & 496 & 45 & $\% 9,07$ \\
\hline Ali oğlu Mehmed & 586 & 54 & $\% 9,21$ \\
\hline Ali oğlu Ahmed & 556 & 44 & $\% 7,91$ \\
\hline Osman oğlu Mustafa & 533 & 35 & $\% 6,56$ \\
\hline Hasan oğlu Ali & 579 & 54 & $\% 9,32$ \\
\hline Halil oğlu Osman & 910 & 54 & $\% 5,93$ \\
\hline Halil oğlu Hüseyin & 678 & 54 & $\% 7,96$ \\
\hline$[\ldots]$ oğlu Yusuf & 492 & 54 & $\% 10,97$ \\
\hline Hamza oğlu Nasuh & 433 & 54 & $\% 12,47$ \\
\hline Salih oğlu Mehmed Ali & 404 & 44 & $\% 10,89$ \\
\hline Durmuş oğlu Ferhad & 602 & 54 & $\% 8,97$ \\
\hline Durmuş oğlu Ömer & 368 & 44 & $\% 11,95$ \\
\hline Veli oğlu Salih & 704 & 54 & $\% 7,67$ \\
\hline Durmuş oğlu Salih & 662 & 54 & $\% 8,15$ \\
\hline Hasan oğlu Salih & 466 & 44 & $\% 9,44$ \\
\hline Behram oğlu Ali & 642 & 54 & $\% 8,41$ \\
\hline Ebubekr oğlu Salih & 546 & 44 & $\% 8,05$ \\
\hline Osman oğlu Kaya & 581 & 54 & $\% 9,29$ \\
\hline Kaya oğlu Ömer & 490 & 35 & $\% 7,14$ \\
\hline Salih oğlu Yusuf & 346 & 20 & $\% 5,78$ \\
\hline Ahmed oğlu Behram & 345 & 25 & $\% 7,24$ \\
\hline
\end{tabular}


Tarih ve Gelecek Dergisi, Ağustos 2019, Cilt 5, Sayl 2

\begin{tabular}{|c|c|c|c|}
\hline Veli oğlu Hasan & 566 & 54 & $\% 9,54$ \\
\hline Ebubekr oğlu İbrahim & 445 & 45 & $\% 10,11$ \\
\hline Hasan oğlu Ömer & 491 & 40 & $\% 8,14$ \\
\hline Musa oğlu Bekir[?] & 630 & 40 & $\% 6,34$ \\
\hline Yusuf oğlu Ali & 519 & 50 & $\% 9,63$ \\
\hline Hasan oğlu Salih & 556 & 50 & $\% 8,99$ \\
\hline Mustafa oğlu İbrahim & 538 & 44 & $\% 8,17$ \\
\hline Hasan oğlu Salih & 551 & 50 & $\% 9,07$ \\
\hline Halil oğlu İlyas & 585 & 50 & $\% 8,54$ \\
\hline İbrahim oğlu Ömer & 666 & 54 & $\% 8,10$ \\
\hline Ebubekr oğlu Halil & 529 & 54 & $\% 10,20$ \\
\hline Ya kub oğlu İbrahim & $116+400($ oğlunun $)=516$ & 44 & $\% 8,52$ \\
\hline Yusuf oğlu İbrahim & 442 & 54 & $\% 12,21$ \\
\hline İbrahim oğlu Yusuf & 450 & 44 & $\% 9,77$ \\
\hline Mehmed oğlu Nasuh & 400 & 30 & $\% 7,30$ \\
\hline İsma' il oğlu Ebubekr & 420 & 30 & $\% 7,14$ \\
\hline Yusuf oğlu İbrahim & 459 & 34 & $\% 7,40$ \\
\hline Hasan oğlu İbrahim & 570 & 40 & $\% 7,01$ \\
\hline Mehmed oğlu Salih & 619 & 40 & $\% 6,46$ \\
\hline Mehmed oğlu Durmuş & 472 & 25 & $\% 5,29$ \\
\hline
\end{tabular}


Ek II ${ }^{27}$ :

Kuruş'un Türk Lirası olarak eşdeğerleri, 1841-1918

\begin{tabular}{|c|c|c|c|}
\hline$\underline{Y I I}$ & $\begin{array}{r}1 \text { kurusun } 2003 \text { yilı } \\
\text { ortasındaki dejeri } \\
(000 \mathrm{TL})\end{array}$ & Yil & $\begin{array}{r}1 \text { kurusun } 2003 \text { yth } \\
\text { ortasındaki degeri } \\
(000 \mathrm{TL})\end{array}$ \\
\hline 1841 & 1134 & 1887 & 798 \\
\hline 1846 & 1106 & 1888 & 826 \\
\hline 1847 & 1246 & 1889 & 798 \\
\hline 1848 & 924 & 1890 & 784 \\
\hline 1849 & 1092 & 1891 & 742 \\
\hline 1850 & 1246 & 1892 & 826 \\
\hline 1851 & 1162 & 1893 & 826 \\
\hline 1852 & 1162 & 1894 & 910 \\
\hline 1853 & 1078 & 1895 & 896 \\
\hline 1856 & 658 & 1896 & 924 \\
\hline 1857 & 658 & 1897 & 952 \\
\hline 1858 & 630 & 1898 & 952 \\
\hline 1859 & 714 & 1899 & 966 \\
\hline 1860 & 714 & 1900 & 966 \\
\hline 1861 & 602 & 1901 & 1036 \\
\hline 1862 & 672 & 1902 & 1022 \\
\hline 1867 & 742 & 1904 & 966 \\
\hline 1868 & 742 & 1905 & 924 \\
\hline 1869 & 812 & 1906 & 924 \\
\hline 1870 & 714 & 1908 & 798 \\
\hline 1871 & 756 & 1909 & 784 \\
\hline 1872 & 700 & 1910 & 770 \\
\hline 1873 & 644 & 1911 & 714 \\
\hline 1874 & 714 & 1912 & 658 \\
\hline 1875 & 770 & 1913 & 658 \\
\hline 1876 & 798 & 1914 & 658 \\
\hline 1877 & 770 & 1915 & 658 \\
\hline 1879 & 812 & 1916 & 369 \\
\hline 1880 & 812 & 1917 & 123 \\
\hline 1884 & 910 & 1918 & 52 \\
\hline
\end{tabular}

Not. Tablodaki verier Prof. Dr. Sevket Pamuk tarafindan hazilianan " Istanbul ve Diger Kentleede 500 Yillik Fiyatiar ve Ocretier, 1469-1998 " adh yayindan yararlanilarak hesaplanmeghti.

27 Tevfik Güran, Osmanlı Malî İstatistikleri Bütçeler 1841-1918, T.C. Başbakanlık Devlet İstatistik Enstitüsü Tarihi İstatistikler Dizisi Cilt 7, Ankara 2003, s.179. 


\section{Ek III:}

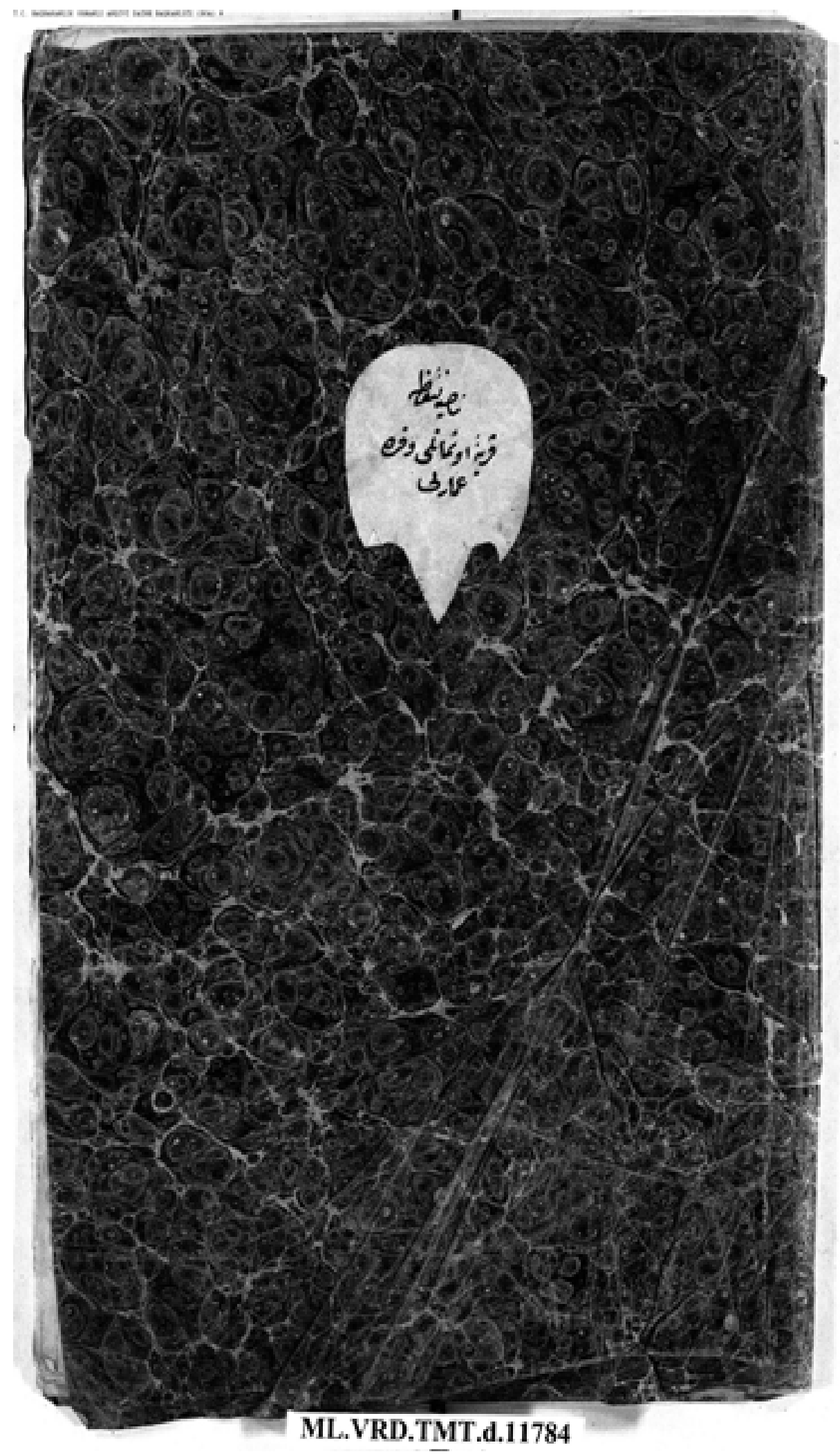


Ek IV:

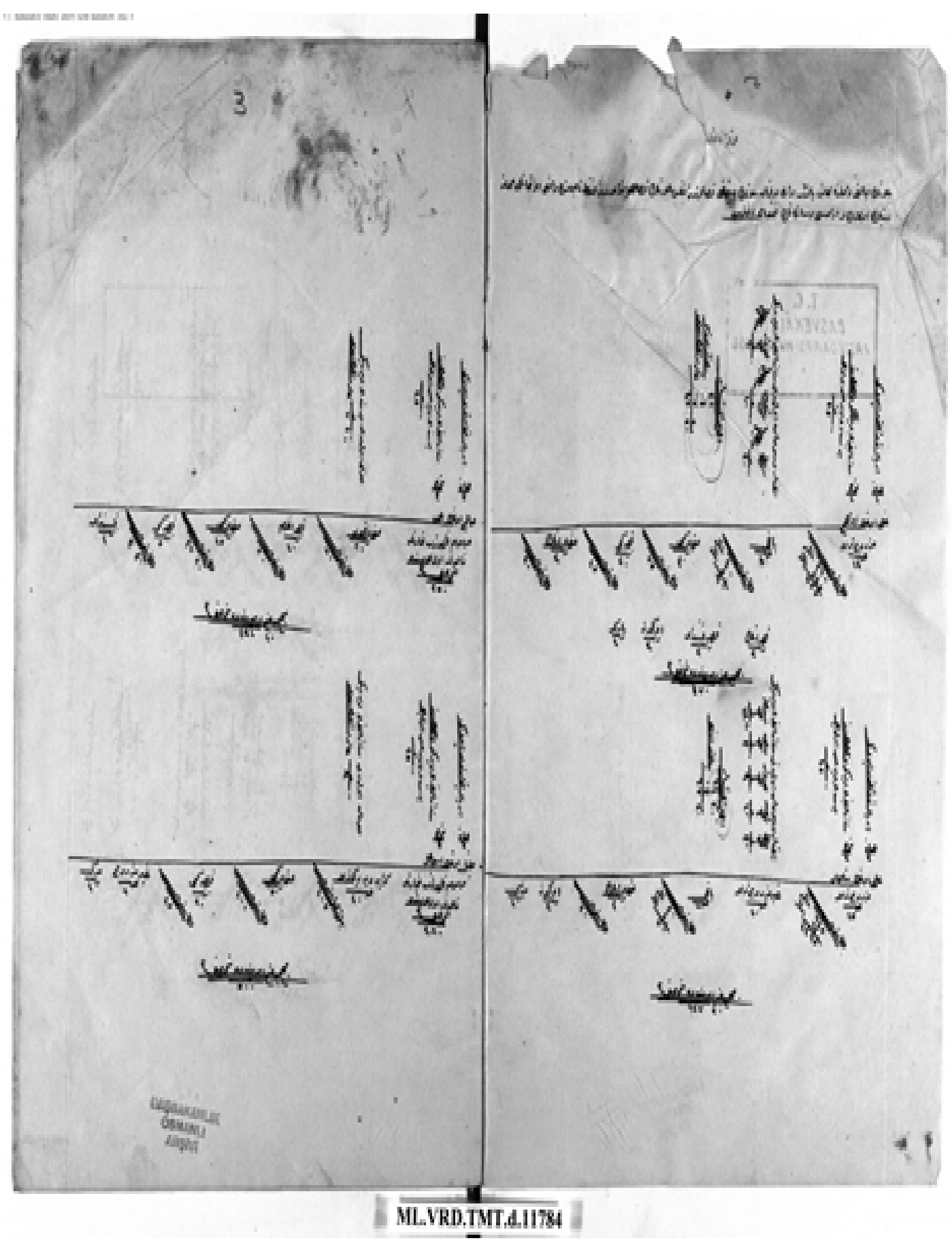


Tarih ve Gelecek Dergisi, Ağustos 2019, Cilt 5, Sayı 2

Journal of History and Future, August 2019, Volume 5, Issue 2

\section{Ek V:}

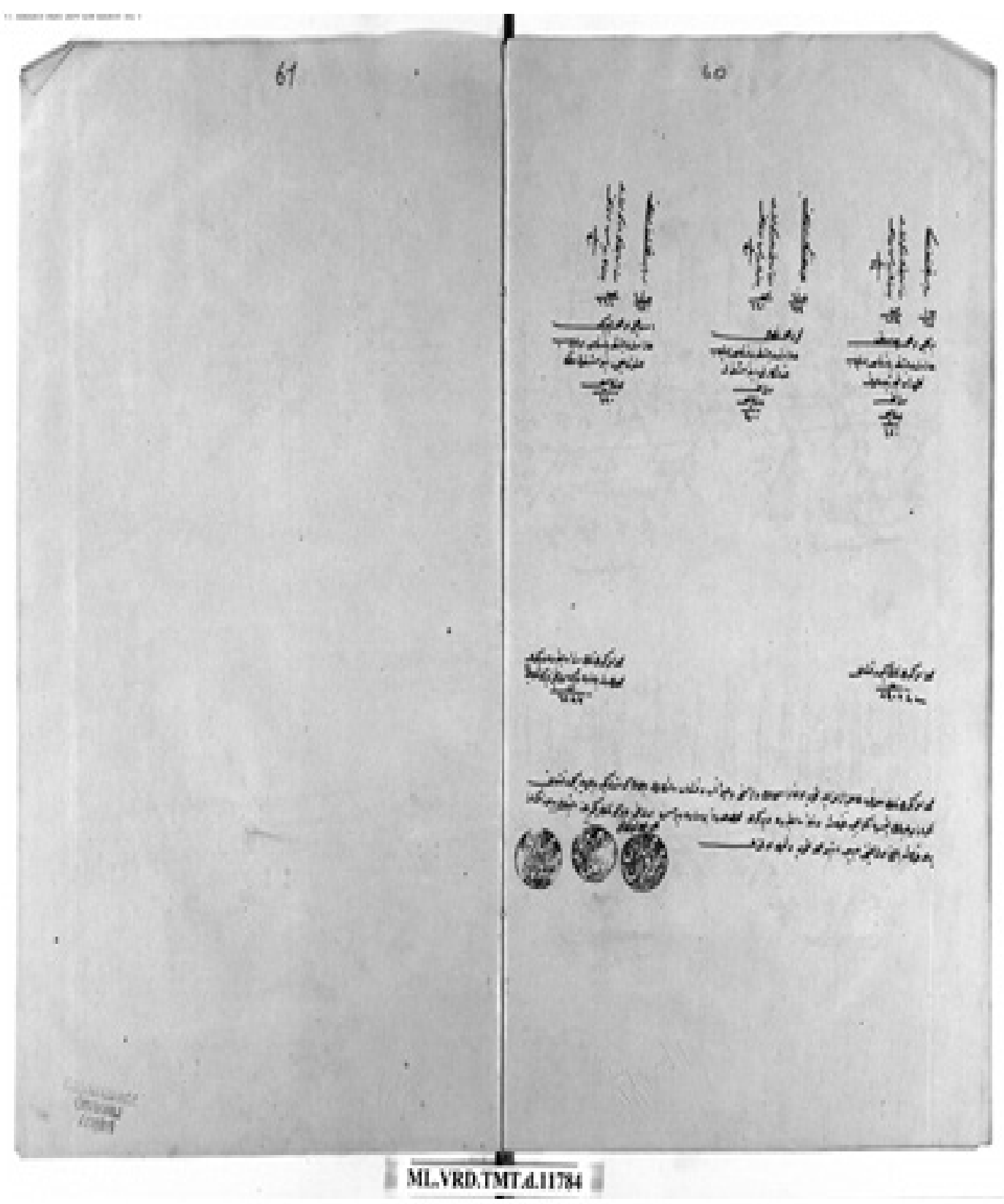

